\title{
Product development with service differentiation in the food industry - a case study
}

\author{
Eduardo Pinheiro Freme Ferreira ${ }^{a}$, Paulo Carlos Kaminski ${ }^{b}$ \\ andependent Consultant \\ 'Polytechnic School of the University of São Paulo \\ e-mails: eduardo.freme@gmail.com; pckamins@usp.br
}

\begin{abstract}
This paper presents relevant aspects of product development with associated services. First, the main topics are introduced by the bibliographical review. After that, a new form to classify services is proposed, since none of the classifications found in the literature was considered to be fully suitable for the needs of this research. A case study is then presented based on five food factories operating in Brazil. The information collected in the companies concerning the development of product-service systems is described and the results are discussed in an integrated form. Finally, recommendations are made about changes in strategy, process and structure that are necessary in order to develop products with service differentiation more efficiently.
\end{abstract}

Keywords: services in the industry, product development, Product Service System (PSS).

\section{Introduction}

Several transformations occurred in production and consumption at the end of the $20^{\text {th }}$ century. One of these changes, which have had significant impact on businesses, is the convergence between industrial and service sectors. "The industrial sector discovers and incorporates the notion of 'service', the service sector industrializes its forms of operation." (ZARIFIAN, 2001, p. 69). In other words, the industrial sector realizes that simply delivering a product is not enough anymore. Some complementary services for the product can significantly increase the consumer's perception of value.

According to Johansson and Olhager (2004), services have become increasingly important for manufacturing companies. Including services that are different from traditional ones in a product is a "[...] powerful means of differentiation recognized by consumers." (MATHIEU, 2001 , p. 44). Schuh, Klotzbach and Gaus (2008, p. 80) complement that "[...] a promising approach for differentiation over competitors is to enhance the existing range of products by offering customer-specific services.". A similar claim is made by Sakao and Shimomura (2007, p. 591): "[...] by designing a set of product and service, the total value increases efficiently".

Santos and Forcellini (2009, p. 39) observe that "[...] the application of concurrent engineering for integrated product and process organization in the 1980s and 1990s provided a competitive differential for companies."

Lara and Cheng (2009, p. 96), discussing about competitive strategy, says "[...] they were still competitive from a market point of view, since the company offered value-adding services in addition to (quality) products and (still up-to-date) technology."

Despite this importance, few studies have been conducted with this specific focus (SHIMOMURA; HARA; ARAI, 2008). Morelli (2006, p. 1495) observes that the designer's role in the development of systems comprising products and services is critical, "[...] although the definition of a specific methodology to manage some critical aspects of the development of this kind of system has seldom been considered in disciplines related to product development.". Sakao and Shimomura (2007, p. 592) also remark that, despite the important potential of offering a product with associated services, "[...] few have tackled so far establishing a method and tool that pursue providing a high value for customers by designing services in parallel with designing products."

In this context, the aim of this paper is to make recommendations concerning relevant aspects of the development project of products with associated services aimed at increasing the perception of value.

\section{Bibliographical review}

\subsection{Service definition}

The definition of service is widely discussed in the literature. The objective here is not to have a universal concept of service. The intention is simply to adopt a 
definition that is specific enough for an understanding of how the term "service" is used in this paper.

According to the norm ISO 9000 (INTERNATIONAL..., 2005), there are "[...] four general categories of product: services, information, materials and equipment, and processed materials.". The norm also states that "[...] many products comprise elements that belong to different general categories of products.'. In other words, few products fit into one single category. This definition accepts the fact that it is often difficult to classify something as a physical good or a service, and it makes it clear that these two items may be included in any product delivered to the client.

Still about the general category defined as service, norm ISO 9000 (INTERNATIONAL..., 2005) states that "[...] service is the result of at least one activity performed necessarily on the interface between supplier and client and it generally is intangible."

Therefore, based on the norm and some of Gadrey's ideas (2001), in the case of a product-related service, it is considered in this paper that there is production of service when: organization $\mathrm{A}$, which has or controls technical and human capacity, associates this capacity to the sale of a product to economic agent $\mathrm{B}$, so as to produce useful consequences or generate sensations in $\mathrm{B}$, at a moment of interaction of $\mathrm{B}$ with organization $\mathrm{A}$, so that $\mathrm{B}$ will visualize a greater value in the product offered by $\mathrm{A}$, yet without the possibility of economic circulation of the service independently of the product. This definition does not intend to be precise or comprehensive in situations when services in general are discussed. However, it makes the term "productservice systems" explicit, as it is used in this text.

\subsection{Product Service System (PSS)}

According to Morelli (2006), the industrial model is changing from mass consumption to individual behaviors with highly personalized needs.

Mathieu (2001) also discusses the high degree of complexity of today's consumer needs and the challenges in the competition among companies. For that author, manufacturing companies have developed a growing interest in using product services (after-sales, financial services, training etc.) as a source of competitive advantage. New business models must offer individual solutions to consumers, delivering to them a product-service system (SCHUH; KLOTZBACH; GAUS, 2008).

According to Willians (2007), researches have shown the limitations of strategies based on technological innovations as a solution to the economic and environmental problems of this type of industry.

Another aspect that makes the incorporation of services increasingly evident is the need for sustainable systems that are suitable to new realities of shortage of resources on the planet. Meeting a need by means of a solution formed by material goods (products) and non-material goods (services) brings benefits to the planet compared to purely material solutions (MONT, 2000).

\section{Classification of services}

When services are defined, an important item is the classification of the types of existing services. This is not an easy task and has been widely discussed in the literature. Mathieu (2001) observes that several types of service classification have been proposed and introduces a new classification (Figure 1).

Another classification, with a focus on product-service systems, is proposed by Baines et al. (2007) and is illustrated by Figure 2 .

The classifications proposed by Mathieu (2001) and Baines et al. (2007) are interesting but they can be more detailed. Mathieu (2001) explains the fact that the service may or may not be essential to access and consumption, but does not address the issue of transference (or not) of the asset. Baines et al. (2007) does not address the fact that the service may or may not be essential, but takes into consideration the transfer of the good, of the availability or only of the result. Both definitions may be regarded as complementary. A common point is that none of them proposes a specific classification for the experience. In what Mathieu (2001) regarded as services that support the clients' actions in relation to the products, there are services that generate results to the user without this result necessarily being accompanied by some sensation. On the other hand, there are services in which the only results obtained are sensations. It is important to separate these groups because they may indicate different stages in how services are addressed in companies. Therefore, based on the proposals found in the literature and on the needs of this research, a classification of services was defined and is presented in Figure 3.

Examples are given for each category.

- Type 1 - without transfer of asset - services in which ownership of the asset remains with the supplier and availability of a product or a result is delivered. E.g.: coffee machines, soda machines, use of photocopiers etc.;

\begin{tabular}{|c|c|}
\hline $\begin{array}{c}\text { Traditional services } \\
\text { guarantee adequate functioning } \\
\text { or facilitate access }\end{array}$ & $\begin{array}{c}\text { Advanced services } \\
\text { support client's } \\
\text { individual initiatives }\end{array}$ \\
\hline
\end{tabular}

Figure 1. Classification according to Mathieu (2001).

\begin{tabular}{|c|c|c|}
\hline $\begin{array}{c}\text { Product-oriented } \\
\text { guarantee functionality, } \\
\text { with transfer of ownership }\end{array}$ & $\begin{array}{c}\text { Use-oriented } \\
\text { sale of use or availability } \\
\text { of product, without } \\
\text { transfer of ownership }\end{array}$ & $\begin{array}{c}\text { Result-oriented } \\
\text { sale of result generated by } \\
\text { a product, without transfer } \\
\text { of ownership }\end{array}$ \\
\hline
\end{tabular}

Figure 2. Classification according to Baines et al. (2007). 
- Type 2 - Traditional - they guarantee adequate functioning or access to the product (without these services the product does not work adequately or cannot be accessed by the client). E.g.: delivery, customer service, warranty, repair, financing, refrigeration (for products that require it) etc.;

- Type 3 - Advanced - without these services the product would work without alterations in its main functions (except for experience). E.g.: recycling, product return, product sampling, customization etc.;

- Type 4 - Experience - creation of sensations in the consumer. E.g.: characters associated to products, brands, promotions (raffles, free gifts etc.), guarantee of satisfaction etc.

A matrix (Table 1) was designed to relate some industries to the proposed classification in order to facilitate the understanding of the service concept. The following scale was adopted to relate the industry to the type of service.

- high - the industry strongly uses this type of service;

- medium - the industry has this type of service, but does not use it intensely;

- low - this type of service is not strongly present in the industry.

\section{Case study}

The case study analyzed five food industries operating in Brazil, three of which are originally from that country. Data was collected through: interviews with company employees; observation of some activities of the employees; analysis of articles, news reports, documents, websites; and field visits to supermarkets. Table 2 presents the main business indicators about the companies.

Company $\mathrm{A}$ is mature in relation to some types of service. There is a perception that some services are fundamental to product success. The main example, used as differentiation by the company, is experience. The brands stand out for the appeal to sensations in the consumption relation. Another source of differentiation through services is customization for big clients. The company provides several services, ranging from consultancy to changes in formulations, for clients such as fast-food chains, restaurants, hotels, hospitals etc. Traditional services are also used as potential for competitive differentiation. There are some setbacks to provide these services but their importance is acknowledged.

Company B is an interesting case of offer of products with service differentiation. Characters that evoke feelings in children are intensively used as competitive advantage. There are specific activities to improve this type of service constantly. It should be stressed that in the case of licensed products there are indicators correlating product profitability to the royalties paid to the licensors. This balance must be pursued, since there are minimum values to be paid. It may be considered that performance of the licensed character is evaluated. Regarding traditional services, the company considers the potential of growth that can be created by improving these services.

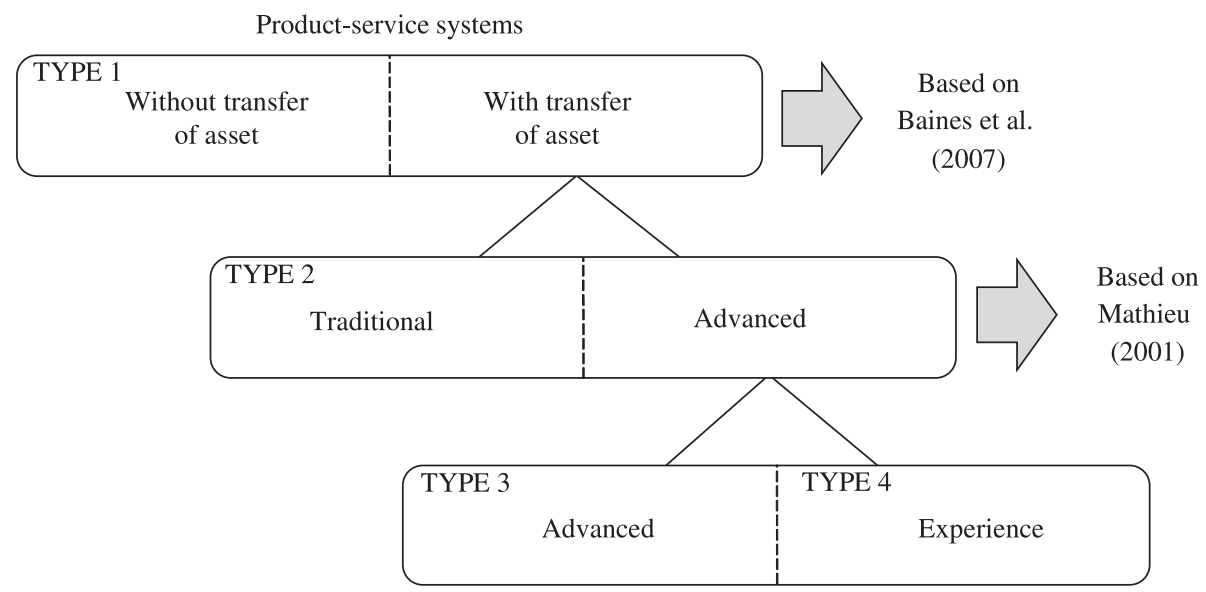

Figure 3. Adopted classification of services.

Table 1. Industries and types of service.

\begin{tabular}{|c|c|c|c|c|}
\cline { 2 - 5 } \multicolumn{1}{c|}{} & $\begin{array}{c}\text { Without transfer } \\
\text { of asset }\end{array}$ & Traditional & Advanced & Experience \\
\hline $\begin{array}{c}\text { Machines and equipment } \\
\text { for the industry }\end{array}$ & High & High & High & Low \\
\hline Home appliances & Low & High & Low & Medium \\
\hline Food & Low & High & Medium & High \\
\hline
\end{tabular}


Table 2. Business indicators.

\begin{tabular}{|c|c|c|c|c|c|c|c|c|}
\hline \multirow{2}{*}{ Indicator } & \multirow[b]{2}{*}{ Unit } & \multirow[b]{2}{*}{ Description } & \multirow[b]{2}{*}{$\begin{array}{l}\text { Average in } \\
\text { the sector }{ }^{1}\end{array}$} & \multicolumn{5}{|c|}{ Company } \\
\hline & & & & $\mathbf{A}^{2}$ & $\mathbf{B}^{1}$ & $\mathrm{C}^{1}$ & $D^{1}$ & $\mathrm{E}^{1}$ \\
\hline Net revenue & $\begin{array}{c}\mathrm{R} \$ \\
\text { Million }\end{array}$ & $\begin{array}{c}\text { Gross revenue minus } \\
\text { taxes, discounts and } \\
\text { returns }^{3}\end{array}$ & 1,100 & 7,283 & 212 & 523 & 1,856 & 6,700 \\
\hline Net profit & $\begin{array}{c}\mathrm{R} \$ \\
\text { Million }\end{array}$ & $\begin{array}{l}\text { Net revenue minus all } \\
\text { costs and expenses } \\
\text { (including interest, } \\
\text { taxes and dividends) }\end{array}$ & 21.5 & $1,238.6$ & 32.1 & 14.2 & 82.3 & 379.9 \\
\hline EBITDA & $\begin{array}{c}\mathrm{R} \$ \\
\text { Million }\end{array}$ & $\begin{array}{l}\text { Profit before interest, } \\
\text { taxes, depreciation and } \\
\text { amortization }^{3}\end{array}$ & 64 & 1,565 & 37 & 67 & 258 & 576 \\
\hline $\begin{array}{l}\text { Number of } \\
\text { employees }\end{array}$ & Units & $\begin{array}{c}\begin{array}{c}\text { Total number of } \\
\text { employees }\end{array} \\
\end{array}$ & N/A & $>12,000$ & $>1,000$ & $>4,000$ & $>9,000$ & $>52,000$ \\
\hline Origin & N/A & Origin & N/A & European & Brazilian & Brazilian & American & Brazilian \\
\hline $\begin{array}{c}\text { Main } \\
\text { segments }\end{array}$ & N/A & $\begin{array}{l}\text { Main segments of } \\
\text { operation }\end{array}$ & N/A & $\begin{array}{c}\text { Juice, } \\
\text { margarine, } \\
\text { tea, seasoning } \\
\text { etc. }\end{array}$ & $\begin{array}{l}\text { Candy, } \\
\text { lollipop and } \\
\text { bubble gum }\end{array}$ & $\begin{array}{l}\text { Semi-ready } \\
\text { products, } \\
\text { pop corn, } \\
\text { seasoning,etc. }\end{array}$ & $\begin{array}{l}\text { Chocolate, } \\
\text { cookies, } \\
\text { powder } \\
\text { juice, juice } \\
\text { etc. }\end{array}$ & $\begin{array}{l}\text { Chicken, } \\
\text { sausage, } \\
\text { bacon, ham } \\
\text { etc. }\end{array}$ \\
\hline
\end{tabular}

${ }^{1}$ Source: VALOR ECONÔMICO. Valor 1000 - 2007 edition. Valor Econômico S.A., year 7, No 7, 2007. ${ }^{2}$ Estimate based on financial reports. Information about the Americas, when feasible, or about the global business was used. ${ }^{3}$ GITMAN (2006).

Company $\mathrm{C}$ has identified an opportunity and has had a strong operation in the segment of semi-ready foods. The consumption experience may be regarded as a central concern and it is one of the service situations under analysis. However, these results more from a specification made for a certain product group based on demands identified in the market rather than from a structured and well-defined process of focus on services. Besides, within the possibilities of sensations evoked in consumption, this is a subtle form. A more practical consumption in general does not inspire feelings as intense as those related to a character for children or to the fact that one feels healthier by consuming a specific margarine. In the children's line the aspect of experience is used more intensely because that is a market in which this type of service is mature and its positive impact is recognized by most companies. There may be other types of services (including the experience) that can be added to the products and that have not been identified due to the lack of a process with such focus.

In company D there is strong concern with some of the traditional services. Delivery and availability are widely considered to be efficient by the market. The Easter service is also regarded as one of best by the market. However, there is still a very clear focus on the physical asset. The services present in most big- and medium-sized food companies have not been implemented yet, such as a website or services targeted at big consumers (fast-food chains, hotels, restaurants etc.). The experience is explored in specific cases and only for some product lines. This hypothesis is supported by the fact that, in interviews and reports about the company, "brand quality" and "product quality" are emphasized as a differential. The brand stands out for its innovations in tangible characteristics of the products, such as packaging, shape, taste, texture etc.

In company $\mathrm{E}$ it was possible to verify that services are a concern. The company has services offered by few companies in the sector, such as a television channel with recipes or the creation of Christmas kits. Specific services for big clients are also important for competitive differentiation. Focus on what was classified in this research as advanced service can be identified. There is also concern with traditional services. Nevertheless, the complexity of the business, mainly in terms of geographical dispersion, has been a challenge in order to preserve quality, mainly in relation to logistics. Experience is an aspect that is not given as much importance as in the other companies. The subject is not addressed in a structured way.

\section{Integrated analysis of results}

Table 3 consolidates and compares the services identified in the companies. The services are grouped according to the classification presented in item 3 . It should be stressed that type- 1 services were not identified in the companies.

The deficiencies found in the companies are consolidated in terms of how the issue of services is handled and how these deficiencies can be transformed into opportunities for improvement (presented at Table 5). 


\section{Considerations to be used in projects}

At first, the opportunities of improvement were grouped to facilitate their analysis. The grouping criterion proposed by the authors was to define how each opportunity relates to the product development process.

The first case is when the opportunity refers to the objectives of the process (it is related to the company strategy). The second case is when the opportunity refers directly to the process (it is related to the activity flow). The third case is when the opportunity refers to the structure that supports the process. Table 4 lists the improvement opportunities and their classification. Many opportunities are related to more than one case. This means that changing only one of them is not enough to solve the problem.

It can be observed that, in the implementation of the proposed actions, there is a logical sequence to be followed. Initially a strategy is defined, then the process that reflects that strategy is designed, and lastly the structure necessary to support that process is defined. It is suggested that, for the change processes proposed below, the actions should be carried out in the same sequence: firstly alterations related to strategy are implemented, next those related to process, and finally those related to structure.
It should be noted that all improvement opportunities are related to strategy. This fact makes sense since in order to have process and structure focused on services it is first necessary to have a strategy with such a focus.

\subsection{Actions related to strategy}

Strategy-related opportunities are those that require changes in the company's vision concerning services. In some cases, it is enough to perform the same activities of the current process and to simply add a focus on services.

\subsubsection{Analysis of service-related cases and data for the sector}

The first step is to raise awareness in the management level (board, directors and high-level management) concerning the potential generation of value in services. This action consists in analyzing the main cases and data about available services to understand the impacts on the business. Some academic papers and books (e.g.: The Service Profit Chain - How Leading Companies Link Profit and Growth to Loyalty, Satisfaction, and Value (HESKETT; SASSER JUNIOR; SCHLESINGER, 1997) analyze the potential impacts on businesses of a focus on services. At the end of this action, the main company management should: be convinced that the focus on services can bring relevant

Table 3. Services identified in the companies.

\begin{tabular}{|c|c|c|c|c|c|c|}
\hline & & \multicolumn{5}{|c|}{ Company } \\
\hline Classification & Service & $\mathbf{A}$ & $\mathbf{B}$ & $\mathrm{C}$ & D & $\mathbf{E}$ \\
\hline \multirow{4}{*}{$\begin{array}{l}\text { Traditional } \\
\text { (Type 2) }\end{array}$} & Customer service (final consumer) & $\mathrm{X}$ & $\mathrm{X}$ & $\mathrm{X}$ & $\mathrm{X}$ & $\mathrm{X}$ \\
\hline & Customer service (intermediate client) & $\mathrm{X}$ & $\mathrm{X}$ & $\mathrm{X}$ & $\mathrm{X}$ & $\mathrm{X}$ \\
\hline & Delivery (wholesalers) & $X$ & $\mathrm{X}$ & $X$ & $X$ & $\mathrm{X}$ \\
\hline & Delivery (small dealers) & $\mathrm{X}$ & & $\mathrm{X}$ & $\mathrm{X}$ & $\mathrm{X}$ \\
\hline \multirow{14}{*}{$\begin{array}{l}\text { Advanced } \\
\text { (Type 3) }\end{array}$} & Product return & $\mathrm{X}$ & & & $\mathrm{X}$ & $\mathrm{X}$ \\
\hline & Product customization & $\mathrm{X}$ & & $\mathrm{X}$ & & $\mathrm{X}$ \\
\hline & Events & $\mathrm{X}$ & & & & \\
\hline & Consultancy & $\mathrm{X}$ & & & & \\
\hline & Promotions (raffles, free gifts etc.) & $\mathrm{X}$ & $\mathrm{X}$ & $\mathrm{X}$ & $\mathrm{X}$ & $\mathrm{X}$ \\
\hline & Creation of kits & $\mathrm{X}$ & & & & $\mathrm{X}$ \\
\hline & Institutional website & $\mathrm{X}$ & $\mathrm{X}$ & $\mathrm{X}$ & & $\mathrm{X}$ \\
\hline & Website of brands & $\mathrm{X}$ & & $\mathrm{X}$ & $\mathrm{X}$ & $\mathrm{X}$ \\
\hline & Product sampling & $\mathrm{X}$ & & $\mathrm{X}$ & $\mathrm{X}$ & $\mathrm{X}$ \\
\hline & Special action with promoters and stands & & & $\mathrm{X}$ & & \\
\hline & Location of retailers & & & $\mathrm{X}$ & & \\
\hline & Magazine & & & & & $\mathrm{X}$ \\
\hline & Television show & & & & & $\mathrm{X}$ \\
\hline & Support to retailer (Easter) & & & & $\mathrm{X}$ & \\
\hline \multirow{4}{*}{$\begin{array}{l}\text { Experience } \\
\text { (Type 4) }\end{array}$} & Lifestyle associated to the product & $\mathrm{X}$ & & $\mathrm{X}$ & $\mathrm{X}$ & $\mathrm{X}$ \\
\hline & Entertainment & $X$ & $\mathrm{X}$ & $X$ & $X$ & \\
\hline & Facility of use & $\mathrm{X}$ & & $\mathrm{X}$ & $\mathrm{X}$ & $\mathrm{X}$ \\
\hline & Licenses & & $\mathrm{X}$ & & & \\
\hline
\end{tabular}


Table 4. Classification of opportunities.

\begin{tabular}{|c|c|c|c|c|c|}
\hline & \multicolumn{5}{|c|}{ Company } \\
\hline Classification & $\mathbf{A}$ & B & C & D & $\mathbf{E}$ \\
\hline Without transfer of asset & Not offered & Not offered & Not offered & Not offered & Not offered \\
\hline Traditional & Regular & Low & Regular & Regular & Regular \\
\hline Advanced & Very high & Low & High & Regular & Very high \\
\hline Experience & Differential & Differential & Very high & Regular & Low \\
\hline
\end{tabular}

results to the business, have estimates of the potential impact, and be able to discern which services make sense in their area/segment of operation.

\subsubsection{Training of employees in services}

Training of company employees in services is a necessary condition for tactical and operational actions to be executed in alignment with the strategy. The depth of training will depend mainly on the role played by the employee. Some employees, such as those working in manufacturing, need only to be aware of the company's new vision about services. Employees with management activities who are responsible for the main decisions of the company should be capable of answering more advanced questions concerning services. This action was classified as strategic because it requires a significant change in the company's vision concerning services. However, it should be followed by the definition of training processes, knowledge measurement and regular updating of employees.

\subsubsection{Hiring a high-management professional specialized/ experienced in services}

Even with an efficient training process in services, the degree of depth of the subject and the change that it represents will mean that some of the knowledge can be constantly lost. It is recommended that someone with academic background and/or great experience in service sectors (e.g.: health, education etc.) should join the management team. This is a way to guarantee that the main concepts will be consolidated in the team, since for at least one of the members these concepts have already been fully incorporated.

\subsection{Actions related to processes}

Process-related opportunities are those that require the review of activities and indicators. In some cases the activity flow is the same and it is only necessary to include a focus on services in their execution.

Changes in certain points of the process cause impact on all following steps because they change the participation of the next phases in the process. Only direct relations were considered in the definition of the relations between improvement opportunities and the proposed actions.

\subsubsection{Grouping of consumers in terms of psychology and demography}

One of the first activities of a survey of market needs is to draw a consumer profile. Consumers are generally grouped by social and economic criteria. Nevertheless, traditional groupings may not reflect important behavior details, which are fundamental for the development of services. In the analysis of the market need for a new margarine, for example, it is necessary to know what exactly consumers expect from this margarine. For some it is important that the product is tasty, for others that it is healthy and for others still that it is as homemade as possible. These different expectations are usually not revealed in socioeconomic perspectives. It is thus important to group consumers according to psychological (how they think and act) and demographic aspects (how they live and are educated).

\subsubsection{Survey of needs with focus on services}

A tangible good with new services is a new product and may significantly vary the portfolio. An ice-cream that starts to have a children character in its package is a new product. Therefore, it is suggested that a list with all possible services for the industry is made. Brainstorming for new service ideas is also relevant. The goal is to guarantee that all the main services have been considered and evaluated as a possibility for the product being developed. A reference for this list is Table 3. It can be used as a checklist of market opportunities to be analyzed.

\subsubsection{Defining product functions with focus on services}

Focus on services requires that functions that are seldom made explicit start to be considered. Some examples would be: entertain children, allow customization, be instant, be practical, be always available, be fun etc. These functions must be made explicit, prioritized and correlated through a function tree in the same way as other tangible functions. This phase is important to improve service quality with the lowest possible cost impact. Cheese can be used as an example. Different clients (mainly hotels, restaurants and hospitals) may want the same cheese with small differences in formulation. If this is identified only at the end of the project, new alterations will demand new developments, 
new tests etc. But if the function "be customizable" is defined since the initial development phase, it is possible to predict the parameters that can be changed and the respective impacts on the product. Therefore, for each service possibility that was mapped, functions should be defined so that, if identified, they will result in the service.

\subsubsection{Defining product concept and architecture with focus on services}

The definitions of product concept and architecture are usually based on tangible aspects. However, it is suggested that these definitions should be based on the concept of product-service system. For functions that have been defined and prioritized, solutions formed by tangible and intangible parts should be considered and the adjustment or interference between these functions should be understood. Brazilian cheese bread can be used as an example. In case the function "be easy to prepare" is defined, it can be satisfied by two concepts: ready-made bread that only requires heating (essentially a tangible product) or a cheese bread mixture to be added to some ingredients. In the second case, a tangible product (mixture for dough) and an intangible product (information to prepare the dough) are being sold. Both concepts can be satisfactory regarding preparation time, but they can have significant cost differences (the ready-made product is highly perishable, and requires constant refrigeration and more complex industrial processes). In other words, the analysis of services to create concepts and define product architecture can increase the possibility of solutions to serve the functions. In practical terms, three actions are suggested. The first is the elaboration of a checklist. The objective is to support the creation of concepts that also incorporate services. Competitors and other sectors may be analyzed to help in the compilation of the list, so that services that can be useful in the product are mapped. Creativity tools can also be helpful to draw up the checklist. The second action is the definition of clear and precise criteria to assign grades to concepts formed by products and services (there is a specific item about methods to define and measure indicators). Comparing concepts with great difference in terms of product-service composition can be complex. The third action is to describe, in the creation of product representations, the associated services for each product module.

\subsubsection{Review of roles and responsibilities in all process phases}

In the vision of product-service systems, it is important that service areas are involved, as much as suitable, in the development process. It is common, for example, to have problems with too many packages being damaged during product transportation because the packages are too sensitive for the company's logistics processes. If the logistics areas are involved in the initial phases of the project, this kind of situation can be anticipated and solved. The suggested action is to review product development processes and subprocesses and to involve people from service areas in appropriate activities.

\subsubsection{Integration of process activities considering tangibles and intangibles}

When defining a time chart of activities that will result in the development of a new product, all service activities existing throughout the project must be considered. A company may have, for example, its product launch delayed by the selection process of service providers that will offer free samples to clients in supermarkets. Service-related processes must be considered at the moment when deadlines and investments in new product development are defined. In this item two actions are suggested. The first is to involve the service areas during the planning phase of a new product so that all resources are allocated considering the service needs. The second is the use of a checklist to verify if all possible services associated to the product have been considered in the allocation of the development project resources.

\subsubsection{Redefinition of public and content of communication}

The means of communication used internally and externally (e-mail, bulletins, newsletters, lectures, training courses, presentations etc.) should be reviewed with a new focus on services. The importance of efficient communication lies in the natural characteristic of services of requiring fast and efficient interfaces between areas. An example would be product customization. Sales, marketing, product development and production areas need to interact integratedly to provide an answer about the possibility of customization. The suggested action is to review the means of communication, the objectives of each communication, the publics involved and the contents made available to each public, respecting information confidentiality policies.

\subsubsection{Mapping of risks considering services}

The risks of a project involving services can be difficult to identify. This is due to the unpredictability inherent to service provision. An example of a risk that is difficult to identify would be the case of a television character (a children's presenter, for instance) that is associated to a product in order to create an experience. There is a risk that this character might do something (such as being involved in a crime), after the product is launched, that will damage his or her image and, consequently, that of the product. In this case two actions are suggested. The first is the presence of people with wide experience in services for the mapping of risks. The second is the creation of a databank with 
identified possible risks related to each type of service. In this way, the risks mapped in one project may be used as a basis for others.

\subsubsection{Definition of criteria to select service providers}

The selection of suppliers to support services has different criteria from the selection of suppliers of mainly tangible goods. For physical goods the priorities are usually cost, quality, reliability etc. In the case of service providers, new criteria have to be evaluated, such as: preparation of the front line, capacity to withstand strong variations in demand, capacity to handle unpredicted situations, capacity to create a positive experience to the client, among others. In some cases, these criteria may be more relevant than costs.

The suggested action is to define evaluation criteria and methods to select service providers. The relevance of the defined criteria and the need for new criteria should be evaluated on a regular basis.

\subsubsection{Description of tasks and events that create the service process}

The change of focus from the tangible good to productservice systems affects a significant part of the company's processes. It is thus necessary to redefine the current processes and to develop new processes. When they are conceived, services should be described in terms of tasks and events that create the service process. The first step is to conduct pilot studies of this process to verify if the requirements are met. An example would be consumer goods companies that make promotions offering free gifts in exchange for purchase receipts. Very often the gifts are unavailable or there are long queues to receive them. By simulating the service process and considering the peaks in demand, the service could be adequately dimensioned. The processes that have an interface with the client are critical due to their direct impact on the consumer's perception of quality. The main processes and subprocesses that should be reviewed (or created) are: service process, expectation management process, demand management process (significantly different for tangibles and intangibles), "emotion management" process in the front line, consumer role management process and quality management process.

\subsubsection{Definition of indicators}

The evaluation of services is complex. This activity is a challenge for several reasons, one of the main factors being the subjectivity of the evaluation. Efficient service management should be clear about the indicators to be observed and how they must be measured. Several tools available in the literature can help in this activity. In the definition of "what to measure", the concepts of balance scorecard and indicator trees can be helpful. The objective is to determine which indicators best help to understand the behavior of the business and how they relate to one another. The challenge is to relate service indicators to tangible parts and to relate operational indicators to financial result indicators. In the definition of "how to measure", tools such as SERVQUAL and QFD help to reduce subjectivity in the measurement of indicators. Efficient management of indicators must measure the impacts of the company's actions on its results.

Five main concepts should be present when the management of indicators is defined. The first is that performance evaluation should be conducted globally. Area or subprocess evaluations can result in distorted information. The second is concerning consumer participation in the indicators. Evaluation of the service should be based on the consumer's opinion. Even if the company's perception is that its product meets the client's expectations, this information will only be considered "true" if the client has the same perception. The third concept refers to employee satisfaction, mainly of those in the front line. Client satisfaction and employee satisfaction are directly related. Measuring employee satisfaction can be considered a tool to identify possible problems in product performance. The fourth concept is about the importance of client and employee loyalty. Studies indicate that loyal clients and employees are related to better profitability. The fifth concept refers to the difficulty in assessing the repair value of a badly done service. It is difficult, and sometimes impossible, to measure the impact of a bad service.

\subsection{Actions related to structure}

Structure-related opportunities are those that are still not fully resolved, even when the company has defined its strategy and processes with a focus on services. They consist in allocating resources to facilitate these processes.

\subsubsection{Allocation of human resources specialized in services}

Having project teams with background and experience in services is one way to incorporate the necessary concepts in the team. In the case of services (mainly of employees who have an interface with clients), the worker should have not only technical skills, but also interaction and relationship skills. The suggested action is to hire professionals from traditional service sectors, such as hotels, hospitals and schools (universities) to participate in the product and service development process.

\subsubsection{Suitable environment in interfaces}

Points of sale, stands, employees' appearance, among others, should favor a positive experience. This has to be considered at all moments of interface. For example: if a consumer sees a truck in bad conditions providing 
Table 5. Relationship between opportunities and actions.

\begin{tabular}{|c|c|c|c|c|c|c|c|c|c|c|c|c|c|c|c|c|c|}
\hline $\begin{array}{l}\text { 1) Lack of perception of the } \\
\text { potential value of services }\end{array}$ & $\mathrm{X}$ & $\mathrm{X}$ & $\mathrm{X}$ & & & & & & & & & & & & & & \\
\hline $\begin{array}{l}\text { 2) Lack of accuracy in the } \\
\text { concepts of "product" and } \\
\text { "service" }\end{array}$ & & $\mathrm{X}$ & $\mathrm{X}$ & & & & & & & & & & & & & & \\
\hline $\begin{array}{l}\begin{array}{l}\text { 3) Lack of basic service } \\
\text { concepts }\end{array} \\
\end{array}$ & & $\mathrm{X}$ & $\mathrm{X}$ & & & & & & & & & & & & & & \\
\hline 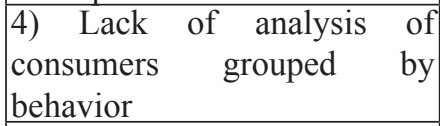 & & $\mathrm{X}$ & $\mathrm{X}$ & $\mathrm{X}$ & & & & $\mathrm{X}$ & & & & & $\mathrm{X}$ & $\mathrm{X}$ & & & \\
\hline $\begin{array}{l}\text { 5) Lack of preparation for "the } \\
\text { moment of truth" }\end{array}$ & & $\mathrm{X}$ & $\mathrm{X}$ & & & & & $\mathrm{X}$ & & & & & $\mathrm{X}$ & $\mathrm{X}$ & & $\mathrm{X}$ & \\
\hline $\begin{array}{l}\text { 6) Lack of perception of the } \\
\text { employee's role in the service } \\
\text { context }\end{array}$ & & $\mathrm{X}$ & $\mathrm{X}$ & & & & & $\mathrm{X}$ & & & & & X & $\mathrm{X}$ & & & \\
\hline \begin{tabular}{|l} 
7) Lack of training and \\
procedures to deal with \\
uncertainties
\end{tabular} & & $\mathrm{X}$ & $\mathrm{X}$ & & & & & $\mathrm{X}$ & & & & & $\mathrm{X}$ & $\mathrm{X}$ & & & \\
\hline $\begin{array}{l}\text { 8) Lack of procedures to } \\
\text { identify service needs }\end{array}$ & & $\mathrm{X}$ & $\mathrm{X}$ & & $\mathrm{X}$ & & & $\mathrm{X}$ & & & & & $\mathrm{X}$ & $\mathrm{X}$ & & & \\
\hline $\begin{array}{l}\text { 9) Lack of focus on } \\
\text { services when defining product } \\
\text { functions }\end{array}$ & & $\mathrm{X}$ & $\mathrm{X}$ & & & $\mathrm{X}$ & & $\mathrm{X}$ & & & & & $\mathrm{X}$ & $\mathrm{X}$ & & & \\
\hline $\begin{array}{l}\text { 10) Lack of focus on services } \\
\text { when defining the concept }\end{array}$ & & $X$ & $X$ & & & & $\mathrm{X}$ & $\mathrm{X}$ & & & & & $\mathrm{X}$ & $\mathrm{X}$ & & & \\
\hline 11) Lack of project integration & & $\mathrm{X}$ & $\mathrm{X}$ & & & & & $\mathrm{X}$ & $\mathrm{X}$ & $\mathrm{X}$ & & & $\mathrm{X}$ & $\mathrm{X}$ & & & $\mathrm{X}$ \\
\hline $\begin{array}{l}\text { 12) Lack of allocation of } \\
\text { specialized human resources }\end{array}$ & & $\mathrm{X}$ & $\mathrm{X}$ & & & & & $\mathrm{X}$ & & & & & $\mathrm{X}$ & $\mathrm{X}$ & $X$ & & \\
\hline $\begin{array}{l}\text { 13) Lack of communication } \\
\text { with focus on services }\end{array}$ & & $X$ & $X$ & & & & & $\mathrm{X}$ & & X & & & $X$ & $X$ & & & $X$ \\
\hline $\begin{array}{l}\text { 14) Lack of risk analysis with } \\
\text { focus on services }\end{array}$ & & $X$ & $\mathrm{X}$ & & & & & $X$ & & & $X$ & & $X$ & $X$ & & & \\
\hline $\begin{array}{l}\text { 15) Difficulty in selecting } \\
\text { suppliers for service-support } \\
\text { activities }\end{array}$ & & $X$ & X & & & & & $X$ & & & & $X$ & $X$ & $X$ & & & \\
\hline $\begin{array}{l}\text { 16) Lack of specific indicators } \\
\text { for service performance }\end{array}$ & & $X$ & $X$ & & & & & X & & & & & $X$ & $X$ & & & \\
\hline
\end{tabular}

\begin{tabular}{|c|c|c|c|c|c|c|c|c|c|c|c|c|c|c|c|c|}
\hline 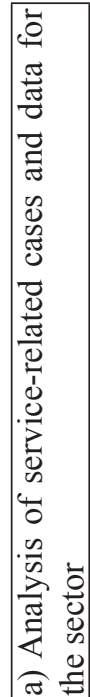 & 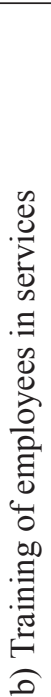 & 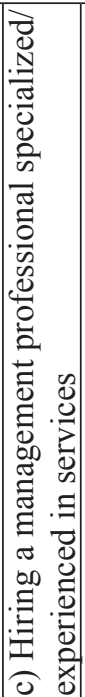 & 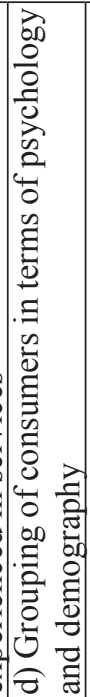 & 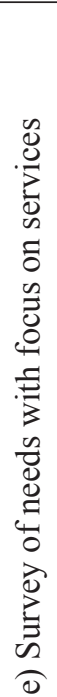 & 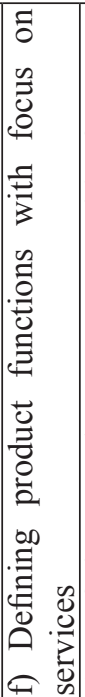 & 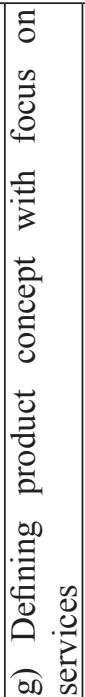 & 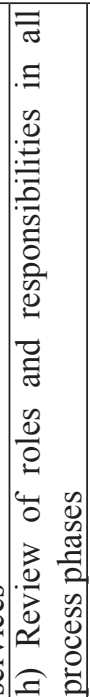 & 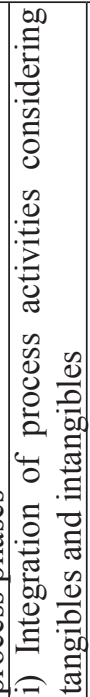 & 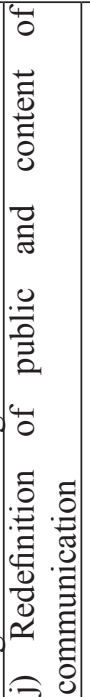 & 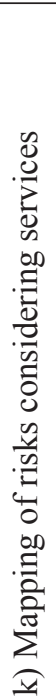 & 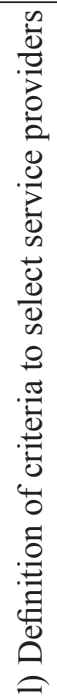 & 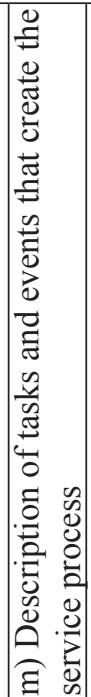 & 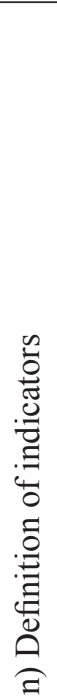 & 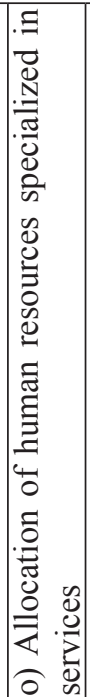 & 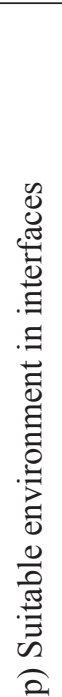 & 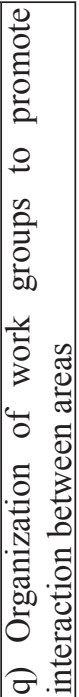 \\
\hline
\end{tabular}


delivery services in a supermarket, he or she may develop a bad opinion about the brand. Even if indirect, this is a form of contact of clients with the brand and they will have impressions about this contact. The recommendation is to create procedures that will identify possibilities of interaction between consumers and brand (either those brands with which the consumer has a strong connection, or those with which the relation is incidental). Once the points of contact are identified, measures should be taken to make sure that these points generate positive experiences to the consumer.

\subsubsection{Organization of work groups to promote interaction between areas}

A focus on services requires interaction between areas that are usually quite distant from each other. An example would be the logistics and marketing areas. Interaction between them can be stimulated by bringing these areas closer through geographical proximity or communication tools (e.g.: videoconferences). Replanning of facilities and work groups is thus recommended to facilitate these interactions. Even if the areas cannot be fully integrated, the formation of work cells with professionals from related areas is suggested.

\subsection{Consolidation of the relationships between opportunities and actions}

Table 5 consolidates the relationships defined between the identified improvement opportunities and the proposed actions. The letter " $x$ " in the table indicates that there is a relation between the improvement opportunity and the proposed action. The improvement opportunities are related to the proposed actions.

\section{Conclusion}

This paper presents four relevant contributions concerning the development of products with differentiation in services. The first is a new proposal for the classification of services, based on some classifications made by other authors. The proposal consists of four groups of product-related services: without transfer of asset, traditional, advanced and experience.

The second contribution is the case study about five food industries operating in Brazil. Data collection and the integrated analysis of the results enable an overview of the current stage of these companies in the development of product-service systems.

The third contribution, and the main objective of this study, was to identify the need for modifications in the companies and to propose actions to be implemented with a focus on a more effective development of products with associated services. The mapping of improvement opportunities not only reaches the initial objective, but can also serve as a checklist for companies that wish to assess the adequacy level of their product development processes in relation to the focus on services.

The fourth contribution is the methodology used to identify opportunities and define improvement actions. The method, which consists of a bibliographical review and a case study designed to enable the identification of opportunities in the companies concerning product-service systems, proved to be efficient.

In the future the research intends to apply the proposed methodology in one of the companies used in the case study in order to measure the impact of implementing the proposed actions. There is also the intention to conduct similar case studies in companies from other sectors.

\section{References}

BAINES, T. S. State-of-the-art in Production-service Systems. Proceedings of the Institution of Mechanical Engineers, Part B: Journal of Engineering Manufacture, v. 221, n. 10 , p. 1543-1552, 2007. http://dx.doi. org/10.1243/09544054JEM858

GADREY, J. Emprego, produtividade e avaliação do desempenho dos serviços. In: SALERNO, M. S. Relação de Serviço: produção e avaliação. São Paulo: Senac, 2001. p. 25-65.

GITMAN, L. J. Principles of managerial finance. Boston: Pearson - Addison Wesley, 2006.

HESKETT, J. L.; SASSER JUNIOR, W. E.; SCHLESINGER, L. A. The Service Profit Chain: how leading companies link profit and growth to loyalty, satisfaction, and value. New York: The Free Press, 1997.

INTERNATIONAL ORGANIZATION FOR STANDARDIZATION - ISO. ISO 9000:2005: Quality management systems - Fundamentals and vocabulary. Geneva: ISO, 2005.

JOHANSSON, P.; OLHAGER, J. Industrial Services Profiling: Matching Services Offers and Processes. International Journal of Production Economics, v. 89 , n. 3, p. 309-320, 2004. http://dx.doi.org/10.1016/ S0925-5273(03)00028-8

LARA, A. P.; CHENG, L. C. A. A proposal for the management of software products aiming at the elaboration of innovation-based competitive strategies. Product: Management \& Development, v. 7, n. 2, p. 91-101, 2009.

MATHIEU, V. Product Services: from a Service Supporting the Product to a Service Supporting the Client. Journal of Business \& Industrial Marketing, v. 16, n. 1.p. 39-58, 2001. http://dx.doi.org/10.1108/08858620110364873 
MONT, O. Product-service Systems. Stockholm: The International Institute of industrial Environmental Economics; Lund University, 2000.

MORELLI, N. Developing New Product Service Systems (PSS): Methodologies and Operational Tools. Journal of Cleaner Production, v. 14, n. 17, p. 1495-1501, 2006. http://dx.doi.org/10.1016/j.jclepro.2006.01.023

SAKAO, T.; SHIMOMURA, Y. Service Engineering: a novel engineering discipline for producers to increase value combining service and product. Journal of Cleaner Production, v. 15, n. 6, p. 590-604, 2007. http://dx.doi. org/10.1016/j.jclepro.2006.05.015

SANTOS, A. C.; FORCELLINI, F. A. Effects of product development decision-making process on the supply chain. Product: Management \& Development, v. 7, n. 1, p. 39-46, 2009.
SCHUH, G; KLOTZBACH, C.; GAUS, F. Service Provision as a Sub-model of Modern Business Models. Production Engineering, v. 2, n. 1, p. 79-84, 2008. http://dx.doi. org/10.1007/s11740-008-0084-6

SHIMOMURA, Y.; HARA, T.; ARAI, T. A Service Evaluation Method using Mathematical Methodologies. CIRP Annals - Manufacturing Technology, v. 57, n. 1, p. 437-440, 2008.

WILLIANS, A. Product Service System in the Automobile Industry: Contribution to System Innovation? Journal of Cleaner Production, v. 15, n. 11-12, p. 1093-1103, 2007. http://dx.doi.org/10.1016/j.jclepro.2006.05.034

ZARIFIAN, P. Mutação dos sistemas produtivos e competências profissionais: a produção industrial do serviço. In: SALERNO, M. S. Relação de Serviço: produção e avaliação. São Paulo: Senac, 2001. 